\title{
Subsidies for propagation of native species in Brazil with medicinal potential: Calophyllum brasiliense Cambess ${ }^{1}$
}

\author{
Rosemeire Carvalho da Silva², Andreza Cerioni Belniaki ${ }^{2}$ iD, Elisa Serra \\ Negra Vieira ${ }^{3}$ (D) Francine Lorena Cuquel $^{2}$ (D), Maristela Panobianco ${ }^{2 *}$ iD
}

\begin{abstract}
Calophyllum brasiliense Cambess. (guanandi) is a native species with medicinal potential and also generates expectation for commercial use (wood) and for recovery of degraded areas. These seeds have physical and mechanical dormancy, requiring techniques for dormancy release; knowledge of seed and seedling morphology that assists laboratory analysis and propagation of the species is also necessary. The objective of this study was to describe the morphological structures of the seeds and normal and abnormal seedlings of guanandi, and also investigate if complete extraction of the endocarp and the seed coat to overcome dormancy will affect the morphology and initial plant development, and consequently production of transplants. Guanandi seeds are large (1000 seed weight of $1480.9 \mathrm{~g}$ ) with a hard seed coat; cotyledons account for most of the embryo and serve as a reserve; the embryonic axis is small $(1.0-2.0 \mathrm{~mm})$ in relation to the seed, yet it is differentiated. The seedlings have hypogeal cryptocotylar germination, with cotyledonary petioles, taproot, and epicotyl developing into a long stem and a tip protected by cataphylls. The main abnormalities in seedlings are related to the root system. Extraction of the endocarp and seed coat does not alter the morphology of seedlings and promotes their greater development, which may be an advantageous strategy.
\end{abstract}

Index terms: guanandi, morphology, seedlings, seeds.

\section{Subsídios para propagação de espécie nativa do Brasil com potencial medicinal: Calophyllum brasiliense Cambess}

\begin{abstract}
RESUMO - Calophyllum brasiliense Cambess. (guanandi) é uma espécie nativa com potencial medicinal e também com expectativa para exploração comercial (madeira) e recuperação de áreas degradadas. As sementes apresentam dormência física e mecânica, exigindo técnicas para superação, e necessitam de conhecimento da morfologia de sementes e plântulas que subsidie as análises em laboratório e a propagação da espécie. O objetivo desse trabalho foi descrever as estruturas morfológicas de sementes e plântulas normais e anormais de guanandi, e também investigar se a completa extração do endocarpo e do tegumento, para superação de dormência, interfere na morfologia e no desenvolvimento inicial da planta e, consequentemente, na produção de mudas. Sementes de guanandi são grandes (peso de mil sementes de $1.480,9 \mathrm{~g}$ ), envoltas em endocarpo rígido; cotilédones respondem pela maior parte do embrião e têm função de reserva; eixo embrionário é pequeno (1,0-2,0 mm) em relação à semente, porém diferenciado. As plântulas apresentam germinação hipógea criptocotiledonar, com pecíolos cotiledonares, raiz pivotante, epicótilo desenvolvendo em haste longa e ápice protegido por catafilos. As principais anormalidades observadas em plântulas são relacionadas ao sistema radicular. A extração do endocarpo e do tegumento não altera a morfologia da plântula e proporciona maior desenvolvimento, podendo ser uma estratégia vantajosa.
\end{abstract}

Termos para indexação: guanandi, morfologia, plântulas, sementes.

\section{Introduction}

Morphological characterization of seeds and seedlings of native forest species stems from increasing interest in their

\footnotetext{
${ }^{1}$ Submitted on 09/13/2018. Accepted for publication on 03/19/2019.

${ }^{2}$ Departamento de Fitotecnia e Fitossanidade, Universidade Federal do Paraná, 80035-050 - Curitiba, PR, Brasil.
}

propagation and in expanding sales of seeds and material for transplanting. Information regarding the morphological characteristics of the fruit and seed assist in identifying how these species respond (Almeida-Júnior et al., 2010;
${ }^{3}$ Embrapa Florestas, Caixa Postal 319, 83411-000 - Colombo, PR, Brasil.
${ }^{*}$ Corresponding author <maristela@ufpr.br $>$ 
Ferreira and Barretto, 2015). This tool has also been used for seed identification in soil seed banks (Seubert et al., 2016), assistance in studies of natural regeneration, and recognition of species in nurseries that produce plants for transplanting (Silva et al., 2008).

Another aspect not greatly discussed but of fundamental importance is the use of knowledge of seed morphology and of initial plant (seedling) growth to assist assessments in the area of seed technology (Ramos and Ferraz, 2008; Gordin et al., 2012), i.e., assist the seed analyst in judgment and classification of normal and abnormal seedlings, as well as in identification of the types of abnormalities present.

In regard to native forest species, few studies report the morphological and fundamental characteristics of a normal seedling, and this lack of studies extends to Calophyllum brasiliense Cambess., a native, non-endemic species popularly known as guanandi found in the Amazon, Cerrado, and Atlantic Forest biomes of Brazil, which has adapted to both waterlogged and well-drained soils (Schultz, 2011). It is a plant with high lumber potential (Barreiros et al., 2016), and it may be grown especially in areas near watercourses, where the soil is generally not highly valued (Oliveira and Joly, 2010).

In addition to its relevance in reforestation aiming at ecological use of wood, thus preventing extraction in areas of native forest, the species has also attracted great interest in the pharmaceutical area due to its chemical composition, exhibiting analgesic (Isaias et al., 2004), antileishmania (Domeneghetti et al., 2018; Cardoso et al., 2017), antiviral (Bernabé-Antonio et al., 2010), trypanocidal (Rea et al., 2013), and anticancer (Garcia et al., 2017; Gómez-Verjan et al., 2019) activity, as well as promising results in treatments of gastrointestinal problems (Lemos et al., 2012; Lemos et al., 2017).

Calophyllum brasiliense seeds are recalcitrant (Silva et al., 2014), i.e., they are sensitive to desiccation, and they have a short life in storage. In addition, they have physical and mechanical dormancy arising from the rigid endocarp that surrounds the embryo; complete removal of this structure is an alternative for dormancy release (Silva et al., 2014).

Thus, there is the need to deepen studies to observe the effects of complete removal of seed covering in seedling morphology to establish standards for interpretation of quality analysis of seeds of the species. In the Instructions for Forest Species Seed Analysis (Brasil, 2013), there is reference to some studies related to the germination test of the species; however, the morphological aspects of guanandi seeds and seedlings are not dealt with.

The aim of this study was to describe the main morphological structures of the seeds and of normal and abnormal seedlings of guanandi, and investigate if complete extraction of the endocarp and of the seed coat for dormancy release may affect the morphology and hurt normal development of seedlings and, consequently, production of plants for transplanting.

\section{Material and Methods}

Ripe fruit of Calophyllum brasiliense was collected from a population composed of 15 trees, within a maximum distance of approximately two kilometers between the first and last tree selected in a natural area of Atlantic Forest in the municipality of Pontal do Paraná $\left(25^{\circ} 35^{\prime}\right.$ S and $48^{\circ} 33^{\prime} \mathrm{W}$ ) in a subtropical climate, according to the Köppen classification.

As soon as the fruit was collected, it was manually pulped, washed in running water, and placed to dry on paper toweling for 48 hours in an environment with controlled temperature of $20 \pm 2^{\circ} \mathrm{C}$.

For physical and morphological characterization of the seeds and seedlings, whole seeds were used, with the presence of endocarp and seed coat (Figure 1A). The following evaluations and observations were made: 1000 seed weight (eight replications of 100 seeds each, coming from the "Pure Seed" portion) and determination of moisture content (laboratory oven method at low temperature of $101-105^{\circ} \mathrm{C} / 17 \mathrm{~h}$, with two replications of five whole seeds each) (Brasil, 2009b); seed diameter (performed through measuring the central diameter of 100 seeds with a digital caliper with precision of $0.1 \mathrm{~mm}$ ); and description of the outer and inner morphological characteristics of the seeds (for better visualization of the embryonic axes, they were extracted and stained in $1 \%$ tetrazolium solution for two hours at $40{ }^{\circ} \mathrm{C}$, and observations were made assisted by a stereoscopic microscope).

For description and morphological characterization of the seedlings, 200 seeds were sown in plastic boxes with perforations in the bottom (filled with medium texture vermiculite) and kept in a greenhouse, with daily watering. Observations were made every seven to ten days, beginning at rupture of the endocarp observed in unearthed seeds. Evaluations were concluded when the possibility of germination was no longer observed, at 112 days after sowing (DAS). However, at the close of the experiment at 112 DAS, the ungerminated seeds and the normal and abnormal seedlings were observed and described. The seedlings that differed from the pattern exhibited by most of the seedlings throughout the experiment, with impossibility of full development of the essential structures, roots, and/or shoots, were considered abnormal.

Our objective was also to compare the development of seedlings coming from whole seeds and from naked seeds (without endocarp and seed coat - Figure 1A), observing 
possible morphological changes due to this extraction. For that purpose, 100 naked seeds were sown under the same environmental conditions and periods of observation cited above for whole seeds.

To compare the performance of seedlings obtained from whole seeds and naked seeds, at 112 DAS, 20 samples from each treatment were collected at random and divided into four replications of five seedlings, and the following evaluations were made: seedling length; root collar diameter; dry matter of seedlings and of cotyledons, i.e., of the reserves not consumed during their development; and root volume, through optical reading with a scanner and analysis by the "Win Rhizo" program.

Descriptive analyses of the data were made and, when necessary, the Bartlett test was used to test homogeneity of the variances, and ANOVA was conducted, with the means compared by the Tukey test $(\mathrm{p} \leq 0.05)$ using the free software $\mathrm{R}$.

\section{Results and Discussion}

Fruit of the Calophyllum genus is classified as drupe type, and frequently only one seed is formed, which, for its part, is covered by a woody endocarp and a membranous seed coat (Brasil, 2009a). These characteristics were observed in this study since we did not find more than one seed per fruit, and the fruit was surrounded by an extremely rigid structure of brown color, constituting the endocarp (Figure 1A).

As shown in Figure 1A, the layer below the endocarp is constituted by a membranous brown plant tissue, constituting the seed coat (Silva et al., 2018). This seed coat is encompassed by vascular bundles that branch off to one extremity, and are thus called chalazal (i.e., the region of the chalaza) vascular bundles, that join by proceeding from around the seed to the opposite extremity, characterized as the hilum-micropyle region (Almeida et al., 2013). This is a scar left by the connection between the seed and the fruit, and the fruit to the peduncle, which, for its part, connects the fruit to the mother plant.

Upon extracting the seed coat, a large embryo can be seen, occupying the entire inner cavity of the seed (Figure 1A), composed of two strongly joined cotyledons marked by a suture line. At the tip of the cotyledons is the embryonic axis, which can be identified externally by the formation of a protuberance generally of a more yellowish color than

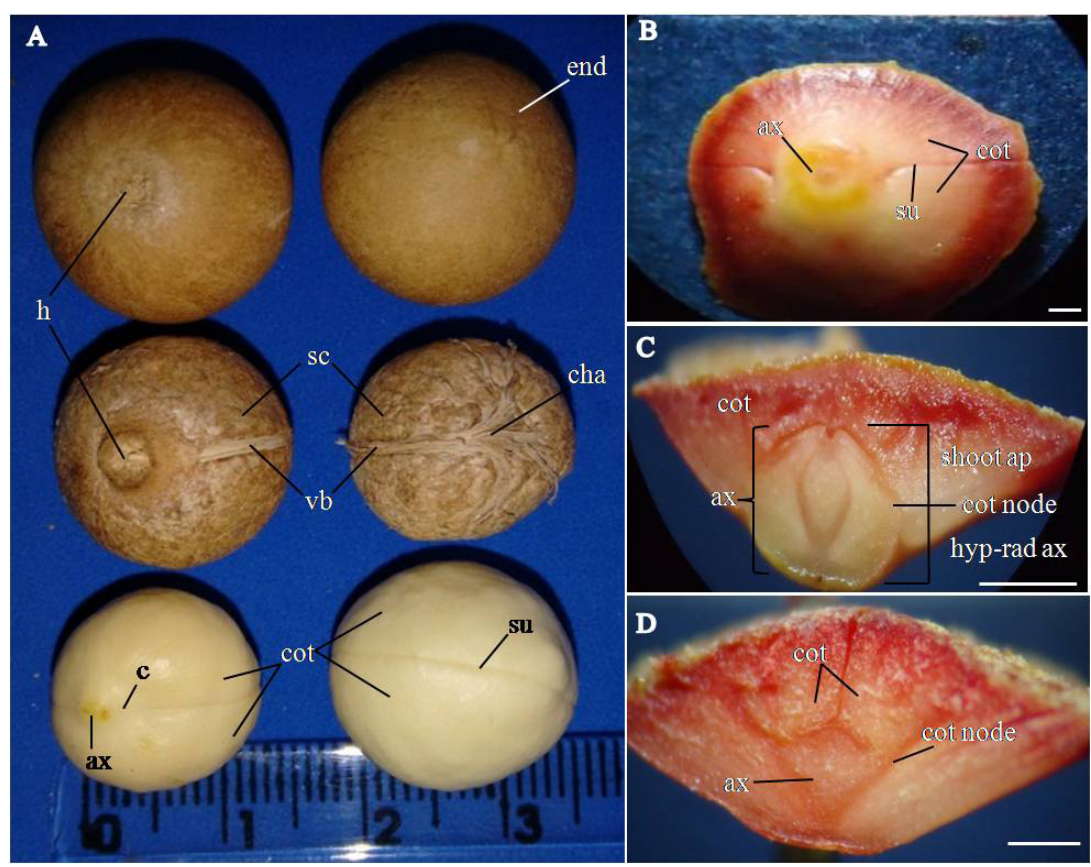

Figure 1. Morphological characterization of the seed and embryo of guanandi. A - whole seeds in the first row, seeds without endocarp in the second row, and embryo alone (without endocarp and seed coat) in the third row, i.e., naked seeds. B embryonic axis with fragments of the cotyledons stained in tetrazolium solution. $\mathrm{C}$ and $\mathrm{D}$ - embryonic axes stained in tetrazolium solution sectioned at the cotyledonary suture and through the cotyledons, respectively. (shoot ap) shoot apex. (c) concave - impression of the hilum left on the embryo. (cha) chalaza. (cot) cotyledon. (end) endocarp. (ax) embryonic axis. (hyp-rad ax) hypocotyl-radicle axis. (vb) chalazal vascular bundles. (h) hilum. (cot node) cotyledonary node. (su) cotyledonary suture. (vs) vascular system. (sc) seed coat. White bars represent scale of $1 \mathrm{~mm}$. 
the color of the cotyledons (Figures 1A and 1B). Another characteristic that assists in identification of the embryonic axis is its location, on the side opposite the branching of the chalaza, below the point of connection of the vascular bundles in the hilum-micropyle region. In this same region, with extraction of the seed coat, a bulging (concave) area can be seen, an impression left by the hilum on the embryo (Figure 1A).

These characteristics are consistent with those of an anatropous seed, originating from an anatropous ovule, which, for its part, is what is most frequently observed in angiosperms. Such seeds have a scar left by the funiculus, i.e., the hilum, near the micropyle, the place where the taproot of guanandi emerges (Figure 2A).

Seed diameter was from 14.0 to $17.6 \mathrm{~mm}$ with a mean of $16.1 \mathrm{~mm}$. The mean 1000 seed weight of guanandi was $1480.9 \mathrm{~g}$, and seed moisture content was $30.1 \%$. According to recommendations from the Rules for Seed Testing (Brasil, 2009b), 1000 seed weight is directly connected with seed moisture content, and may vary in accordance with moisture content. Guanandi seeds are considered to be large since 1000 seed weight is greater than $200 \mathrm{~g}$, as described in the Rules for Seed Testing (Brasil, 2009b).

Guanandi produces fruit and seeds that are globous and of large size, and the embryo occupies the entire inner cavity of the seed (Figure 1A). Cotyledons, specialized in accumulation of reserves, represent nearly the entirety of the embryo, and thus the seed can be classified as exalbuminous (Gonçalves and Lorenzi, 2007), i.e., without endosperm. The characteristic of producing large seeds is frequently observed in forest species of tropical environments. For many researchers, this is considered a way of adapting to the climate conditions to which these species are subjected and to the need for overcoming obstacles, such as predation of animals and insects (Baraloto and Forget, 2007). Guanandi occurs naturally in Brazil in hot and humid regions, and thus it is reasonable that its seeds have characteristics of tropical species.

The embryonic axis is of reduced size (1.0 to $2.0 \mathrm{~mm}$ ) compared to the size of the embryo (Figures $1 \mathrm{C}$ and 1D), but with the aid of a stereoscopic microscope, a certain degree of differentiation could be visualized, because it stands out from the other seed tissues through its rounded shape (Figure 1C). Marked differences can be observed between the shoot apex of the embryonic axis (more rounded epicotyl found in a small cavity formed between the cotyledons) and the opposite apex (more funnel shaped, constituting the hypocotyl-radicle region) (Figure 1C). Between the epicotyl and the hypocotyl-radicle regions is the point of connection of the cotyledons, also called the cotyledonary node. With a cut in the cotyledonary suture, the vascular system of the embryonic axis could be observed in the central region (Figure 1C).

Figure 1D shows the embryonic axis in another perspective, revealing the region of connection of both cotyledons to the axis, the place where the transfer of cotyledon reserves to the embryonic axis occurs. In this section, the suture line between the two cotyledons could be visualized, marking the region when the cotyledons terminate at the center of the embryo, thus forming the cavity where the shoot apex of the embryonic axis (epicotyl) is connected (Figure 1D).

The guanandi seedling has hypogeal cryptocotylar germination, with cotyledon reserves, characterized by the cotyledons remaining attached to the covering of the seeds and below or on the surface of the soil (Brasil, 2009a). A cryptocotylar seedling generally has a highly reduced hypocotyl-radicle axis (Souza, 2009), with significant development after germination, characteristics that were observed in the guanandi seeds and seedlings.

Germination of the guanandi seed begins with growth of the cotyledonary petiole, which assists in breaking through the
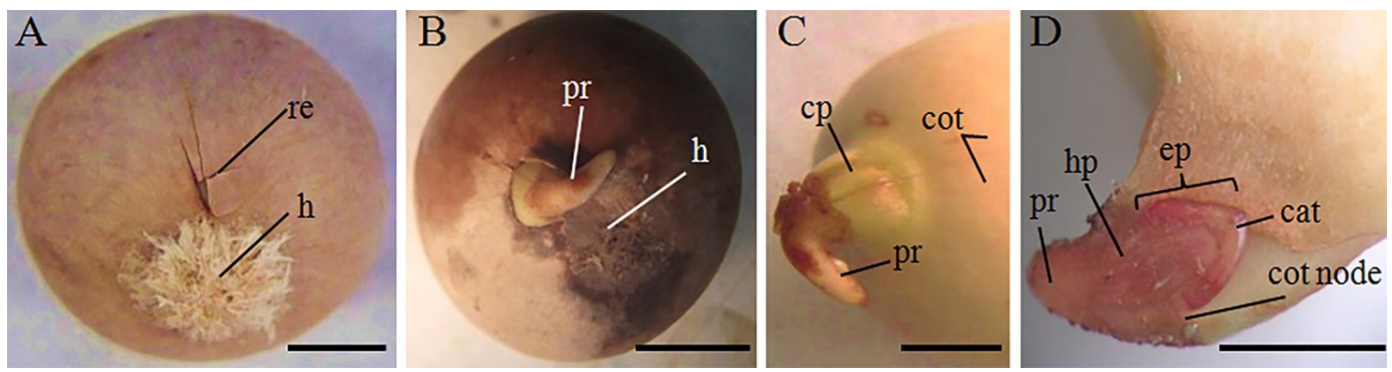

Figure 2. Beginning of seed germination process and initial development of the guanandi seedling. A - rupturing of the endocarp; B - beginning of taproot development; $\mathrm{C}$ and $\mathrm{D}$ - external and internal view of the seedling at the beginning of germination, respectively. (cat) cataphyll. (cot) cotyledon. (ep) epicotyl. (h) hilum. (hp) hypocotyl. (cot node) cotyledonary node. (cp) cotyledonary petiole. (re) root emergence. (pr) primary root. Bars in the corner of the figures represent a scale of $5 \mathrm{~mm}$ in (A) and (B), and $2.5 \mathrm{~mm}$ in (C) and (D). 
woody endocarp, allowing release and growth of the taproot that breaks through the endocarp (Figures 2A, 2B, 3A and $3 \mathrm{~B}$ ). The aboveground part (epicotyl) initially has discrete development and remains protected within the endocarp, between the cotyledonary petioles (Figures $2 \mathrm{C}$ and 2D). The region of the epicotyl is marked by a generally reddish color, which is gradually replaced by green color with the development of the first leaves.

After the endocarp is ruptured (Figure 3A), short cotyledonary petioles are formed, which are characteristic of seedlings whose seeds have cotyledons specialized in accumulation of reserves, and the function of the petiole is to project the root and the plumule out of the seed covering (Figures 3B to 3C). Another common characteristic of these seedlings is the fact of having a short hypocotyl (Figure 3D).

The root originating from the radicle of the embryo is a robust taproot, which develops perpendicular to the seed (Vidal and Vidal, 2007) (Figure 3I). Formation of the first secondary roots was observed at approximately 35 days after rupture of the endocarp, coinciding with initial development of the primary leaves (Figure 3E).

The aboveground part (shoot) of the seedling, the epicotyl, the first internode developed above the cotyledonary node, begins to be projected outward from the endocarp at approximately 30 days after the beginning of germination, forming an orthotropic stem, which raises the apical bud protected by cataphylls up to the surface of the substrate (Figures 3D and 3E). Cataphylls are reduced leaves frequently present in seedlings with hypogeal germination (with the function of protecting the plumule bud), which may be shed or not (Vogel, 1980). In the case of guanandi, the cataphylls lose their function and fall as seedling development proceeds (Figure 3H).

The formation and expansion of the first leaves begin to be observed at 35 days after rupture of the endocarp, and at approximately 40 days, the beginning of formation of the second pair of leaves can be seen (Figures 3E and 3F). The first leaves have characteristics that are very similar to an adult leaf, with marked differences mainly from smaller size and their color, which remains more reddish until reaching full development, when the predominant color becomes green through the action of chlorophyll (Figures $3 \mathrm{~F}$ to $3 \mathrm{H}$ ). Its phylotaxis is predominantly opposite, crossed or decussate; its leaves are petiolate, with a single leaf blade composing a simple leaf of leathery consistency with a hairless surface, entire margins, and oblong shape; and its venation is characteristic of a pinnate leaf, with pointed tip and base (Vidal and Vidal, 2007) (Figures 3F to 3H).

The time necessary for a whole seed to form a normal seedling from the time of rupture of the endocarp was from 40 to 50 days, considering a normal seedling as that with a root system, shoot (epicotyl), and developed and healthy primary leaves, with tolerance for small defects as long as they did not
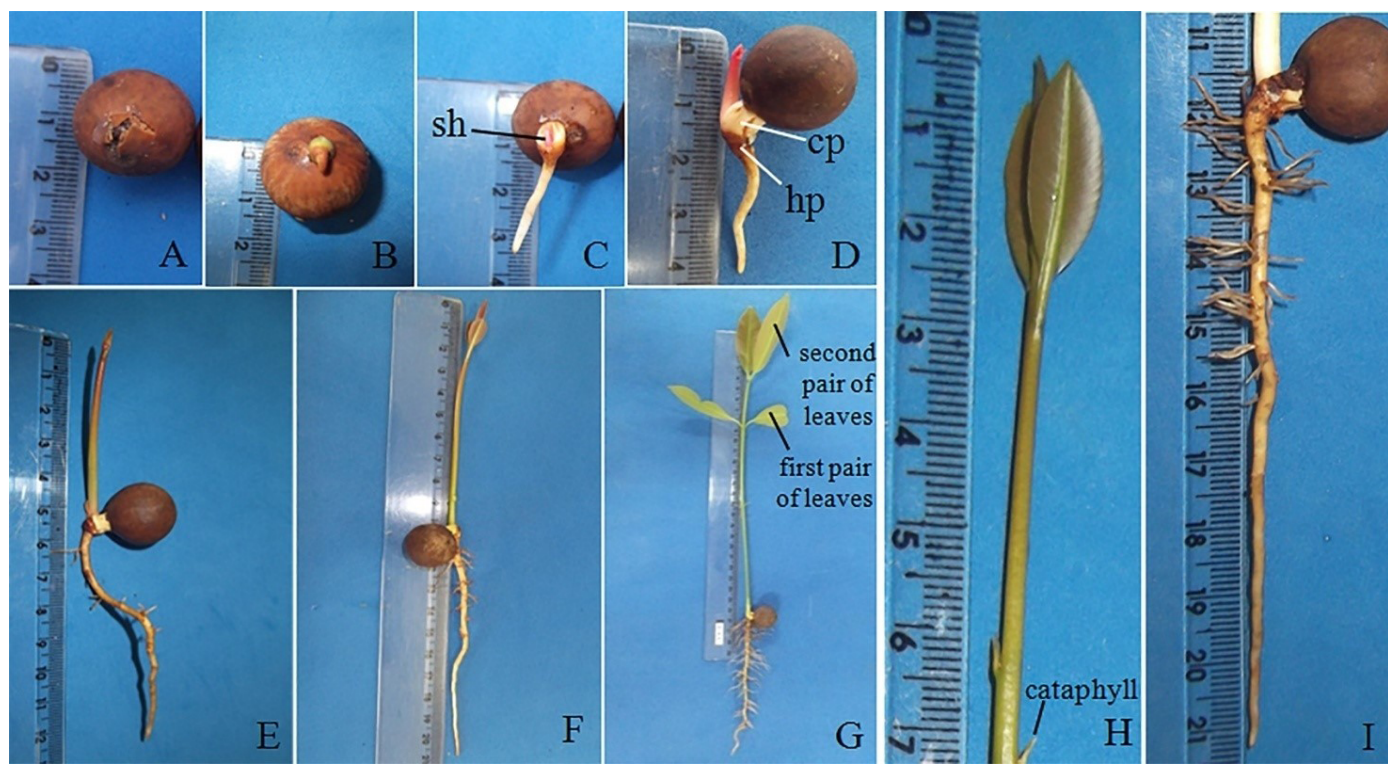

Figure 3. Seed germination process and seedling development of guanandi. A - rupturing of endocarp. B - taproot emergence. $\mathrm{C}$ - beginning of shoot emergence (epicotyl). D - expansion of epicotyl and of taproot. $\mathrm{E}$ - beginning of development of the first pair of leaves and secondary roots. F - normal seedling. $\mathrm{G}$ - plant with full expansion of first pair of leaves and second pair of leaves. $\mathrm{H}$ - detail of the epicotyl, with first pair of leaves in expansion and cataphyll in senescence. I - detail of the roots of the guanandi seedling. (hp) hypocotyl. (sh) shoots. (cp) cotyledonary petiole. 
compromise the development that characterizes the seedlings (Brasil, 2009b). Nevertheless, as the seeds were collected from a natural population, i.e., not the result of breeding, and by the fact of whole seeds exhibiting physical and mechanical dormancy, heterogeneity in seed germination and seedling development was expected, which in fact occurred. Thus, it was necessary to conduct the experiment up to 112 days after sowing (DAS) for the last normal seedling to be evaluated (Figure 4A).

The seedlings coming from naked seeds had the same morphological structure as those from whole seeds; nevertheless, seedling development was faster. At 10 DAS, most of the naked seeds with germination potential had already begun the germination process, with the primary root in development, while whole seeds showed no signs of rupture of the endocarp (Figures 4B and 4C).

Reflections of this difference in development were observed up to the end of the experiment. At 68 DAS, the most vigorous seedlings from the naked and whole seeds had two pairs of leaves; nevertheless, there were perceptible differences in the stage of development of their structures, such as shoots and roots (Figure 4D). At the end of the evaluations at 112 DAS, most of the seedlings coming from naked seeds had from three to five pairs of well-developed leaves, while those from whole seeds had from one to three pairs (Figure 4E). The gain in initial development of the plants from removal of the seed coat was significant in relation to their non-removal (Figure 5).

At 112 days after sowing, naked seeds gave rise to seedlings with total length $28 \%$ greater than those obtained from whole seeds. Seedlings obtained from naked seeds also exhibited a gain of $22 \%$ in diameter of the root collar, $64 \%$ in dry matter, and $55 \%$ in root volume. Nevertheless, they had the same consumption of the cotyledonary reserves (Figures $5 \mathrm{~A}$ to $5 \mathrm{E}$ ), indicating that the seedlings of whole seeds expended more energy and, consequently, their reserves to break through the rigid covering of the seeds, investing less energy in their growth.

A previous study on guanandi seed germination showed advantages in removal of the seed covering, both in percentage and in speed of germination (Silva et al., 2014). Knowing that removal of the endocarp and seed coat from the seeds did not change the morphology of the seedlings and allowed the formation of more developed plants, especially in regard to improvement in root formation, this may be an advantageous strategy for production of guanandi plants for transplanting.

Among the abnormalities observed during the experiment (Figure 6), those related to the roots stand out. Frequent defects were observed in the cotyledonary petiole, often joined and exteriorized, though without developing roots or shoots, or even a petiole completely or partially split, impeding full development of both the roots and the shoots (Figures 6A and $6 \mathrm{~B})$. Other common defects were normal development of the shoots without the presence of roots (Figure 6C) or with defective roots, such as thickening of roots that interrupted their development, causing disproportion between shoots and the root system (Figure 6D); as well as defects in the main root, such as bifurcation or formation of various roots (Figure $6 \mathrm{E}$ ).

The main abnormalities related to the shoots were a
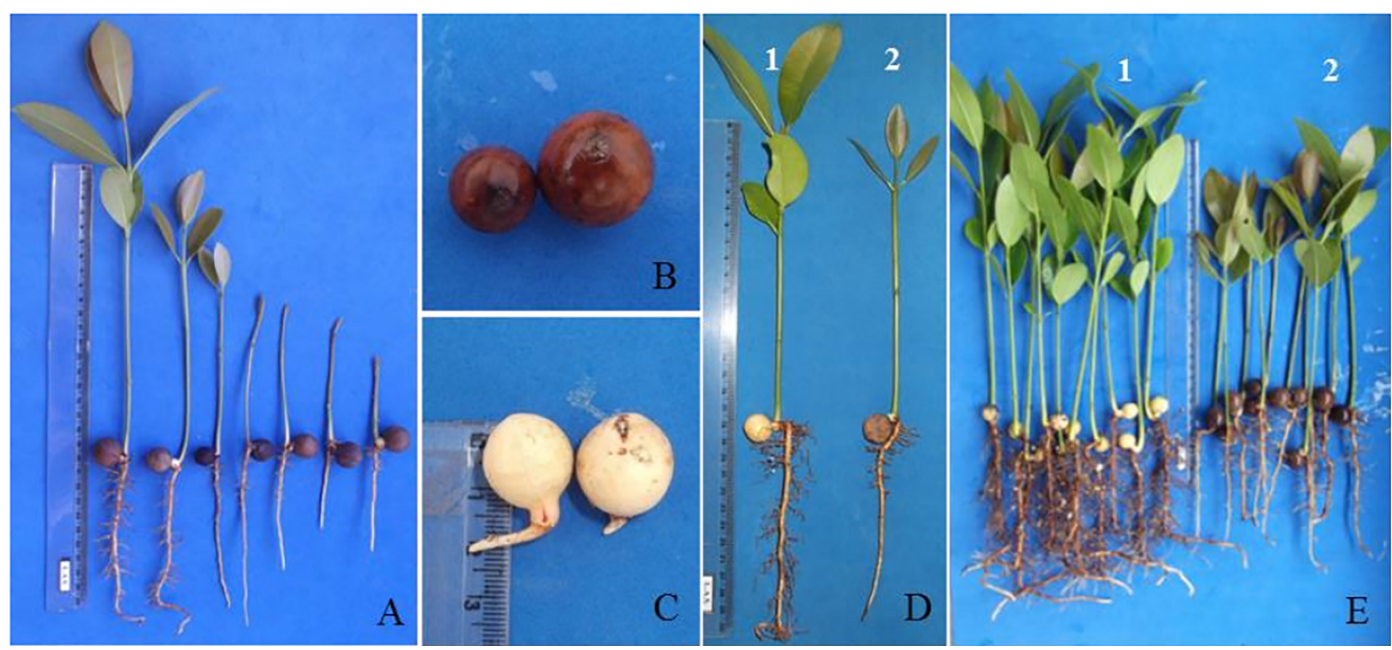

Figure 4. Different stages of development of guanandi seeds and seedlings. A - different stages of normal seedlings coming from whole seeds at 112 days after sowing (DAS). B - whole seeds and C - seedlings at the beginning of germination, coming from naked seeds at 10 DAS. D - general appearance of seedling at 68 DAS. E - comparison between the most vigorous seedlings at 112 DAS. (1) seedlings coming from naked seeds. (2) seedlings coming from whole seeds.

Journal of Seed Science, v.41, n.3, p.318-327, 2019 
highly elongated epicotyl without expansion of the first leaves (Figure 6F); thickening of the basal part of the epicotyl (Figure 6G); and formation of albino seedlings, because the normal guanandi seedlings have reddish or light green color, never white or hyaline (Figure $6 \mathrm{H}$ ).

During the study, it was observed that the shoots of guanandi seedlings are resilient. Seedlings that for some reason were not able to put forth a main stem from the shoot (epicotyl) developed one or more substitute stems from the base of the cotyledons (Figure 6I); nevertheless, in this study, the same capacity of resilience related to the root was not observed.

The seeds with characteristics of accumulation of reserves frequently have buds in the axils of the cotyledons, as a way to repair damage to or loss of the main axis of the seedlings in the initial stages; its reserves are able to sustain one or more new structures. This is a survival strategy of various forest species, especially from humid, tropical forests, which suffer from frequent predation from herbivores and use their reserves to recompose the lost structures (Teixeira and Barbedo, 2012).

The formation of numerous stems (shoots) without predominance of a main stem may be characterized as an abnormality (Figure 6I); nevertheless, as it is a resilience strategy of the species, it may be tolerable. In this case, the tolerance was formation of one or two new stems, with at least one of the stems having well-developed primary leaves and thus considered a normal seedling. The formation of numerous stems, however, was considered an abnormality.

Another particular feature that must be tolerated is the presence of defects in more than $50 \%$ of the cotyledons, since a large amount of cotyledon reserves allows formation of a normal seedling without total expenditure of the reserves. Thus, in the present study, formation of the essential parts of
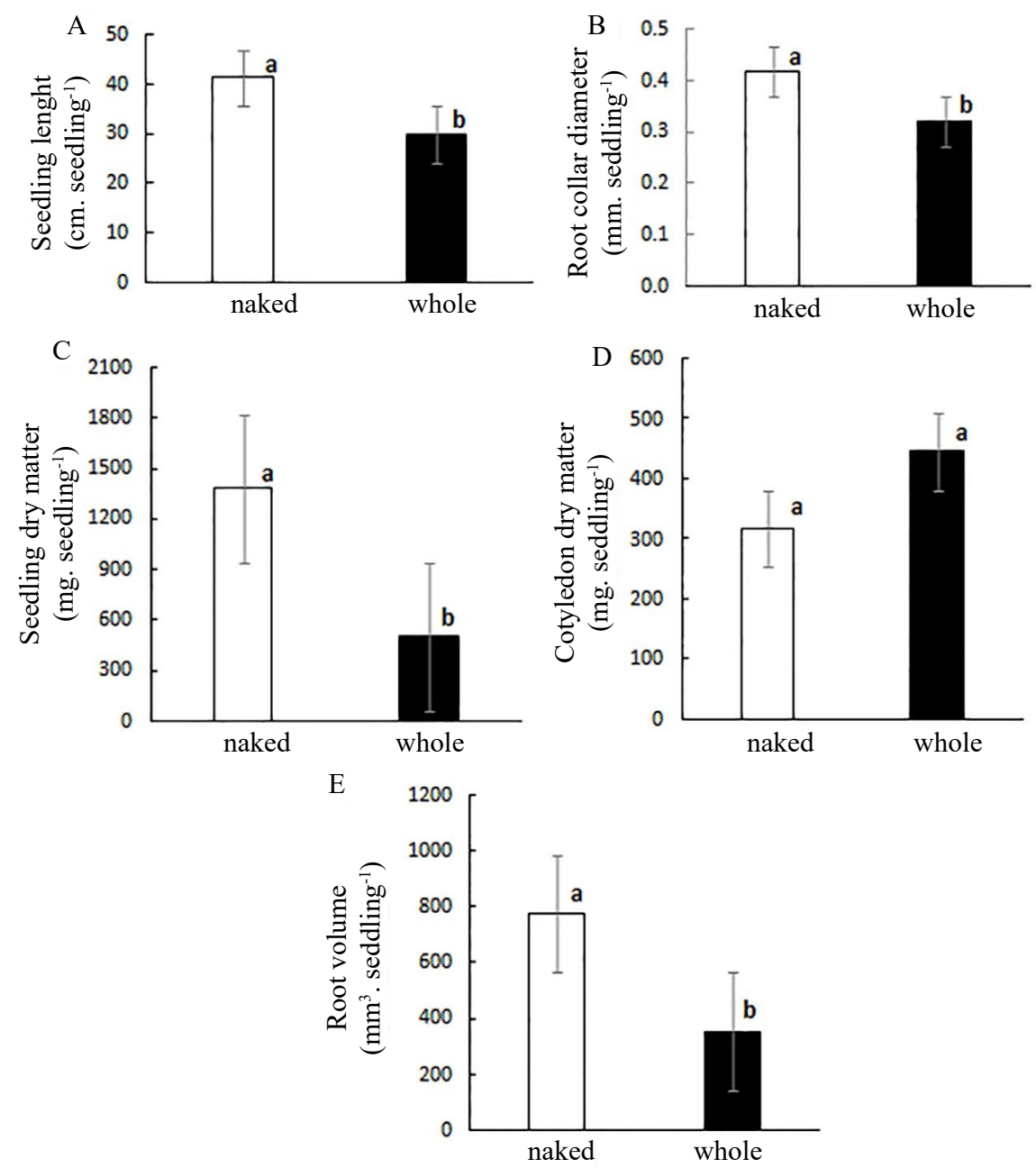

Figure 5. Initial development of guanandi plants coming from whole seeds and naked seeds. A-mean total plant length. $\mathrm{B}-$ mean root collar diameter. $\mathrm{C}$ - mean plant dry matter. $\mathrm{D}$ - mean cotyledon dry matter (non-consumed reserve). $\mathrm{E}-$ mean root volume. The same letters above the columns do not differ statistically by the Tukey test $(\mathrm{p}<0.5)$. 

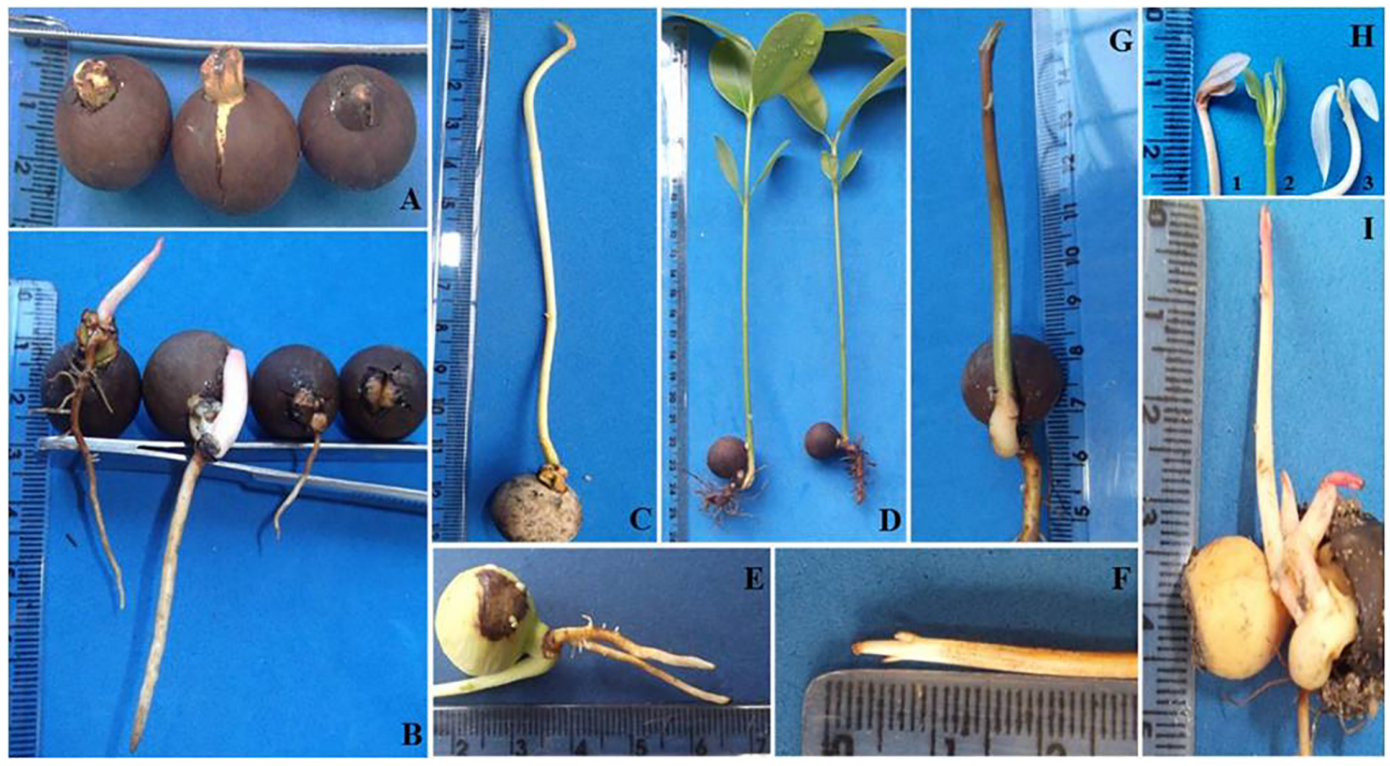

Figure 6. Abnormalities in guanandi seedlings. A and B - defects related to the cotyledonary petiole. $\mathrm{C}-$ seedling with absence of root. $\mathrm{D}$ - seedlings with atrophied roots. $\mathrm{E}$ - seedling with bifurcation of the taproot. $\mathrm{F}$ - epicotyl without expansion of the primary leaves. $\mathrm{G}$ - seedling with thickening at the base of the epicotyl. $\mathrm{H}$ - normal seedlings (1 and 2) with reddish and green color, and abnormal seedling (3) without color (hyaline). I - seedling with sprouting of various stems (shoots).

seedlings was prioritized, even if seedlings exhibited possible defects greater than $50 \%$ in the cotyledons. At the end of 112 days, with the plants completely formed with one to five pairs of well-developed leaves, an average of $375 \mathrm{mg}$ of dry matter remained in the cotyledons, i.e., reserves not consumed during formation of the plant in a favorable environment (Figure 5D).

There are divergences among technicians in the area of seed technology regarding evaluation of the seed structures and of the abnormalities of a forest species seedling, as for example, the percentage of infections in the cotyledons that can be tolerated because, in many cases, less than $50 \%$ of the cotyledons put forth a healthy and vigorous first pair of leaves, as observed for guanandi. This reinforces the need for advances in morphological, physiological, and biological knowledge of each species, in order to correctly interpret the germination test.

In addition, many authors consider that the endocarp (plant tissue belonging to the fruit) can be classified as the outer part of the mesophyll of the seed testa, thus making up part of the seed coat, which reveals the need for additional studies to investigate the true origin of this tissue.

\section{Conclusions}

Guanandi seeds are marked by the presence of a rigid endocarp, membranous seed coat, large cotyledons that function as a reserve and make up most of the embryo, and a very small embryonic axis $(1.0-2.0 \mathrm{~mm})$ that is differentiated into an epicotyl and hypocotyl-radicle axis.

Seedlings have hypogeal crytocotylar germination, with the presence of cotyledonary petioles, a very short hypocotyl, and epicotyl that develops a long stem with protective cataphylls in the apical region; they have a robust taproot; and their shoots exhibit resiliency. The main abnormalities observed in the samples evaluated were related to the root system.

The extraction of the endocarp and of the seed coat does not change the morphology of the seedling and provides advantages in the initial development and growth of the plants, which may be an advantageous strategy for production of guanandi plants for transplanting.

\section{References}

ALMEIDA-JÚNIOR, E.B.; LIMA, L.F.; LIMA, P.B.; ZICKEL, C.S. Descrição morfológica de frutos e sementes de Manilkara salzmannii (Sapotaceae). Floresta, v.40, n.3, p.535-540, 2010. https://revistas. ufpr.br/floresta/article/view/18915/12233

ALMEIDA, O.; PAOLI, A.A.S.; SOUZA, L.A.; COTA-SÁNCHEZ, J.H. Seedling morphology and development in the epiphytic cactus Epiphyllum phyllanthus (L.) Haw. (Cactaceae: Hylocereeae). Journal of the Torrey Botanical Society, v.140, n.2, p.196-214, 2013. http://www.herbarium.usask.ca/research/articles/Almeida_etal_ Epiphyllum_Torrey.pdf

BARALOTO, C.; FORGET, P.M. Seed size, seedling morphology, and response to deep shade and damage in neotropical rain forest trees. American Journal of Botany, v.94, n.6, p.901-911, 2007. https://onlinelibrary.wiley.com/doi/epdf/10.3732/ajb.94.6.901 
BARREIROS, R.M.A.; SIMÕES, S.; MATOS, C.A.O.; COSTA, A.S. Estudo quantitativo da variação estrutural morfológica na madeira de Calophyllum brasiliense. Cerne, v.22, n.1, p.77-84, 2016. http://www. scielo.br/scielo.php?pid=S0104-77602016000100077\&script=sci_arttext

BERNABÉ-ANTONIO, A.; ESTRADA-ZÚÑIGA, M.E.; BUENDÍA-GONZÁLEZ, L.; REYES-CHILPA, R.; CHÁVEZÁVILA, V.M.; CRUZ-SOSA, F. Production of anti-HIV-1 calanolides in a callus culture of Calophyllum brasiliense (Cambes). Plant Cell, Tissues and Organ Culture, v.103, n.1, p.33-40, 2010. https://link.springer.com/article/10.1007/s11240-010-9750-4

BRASIL. Ministério da Agricultura, Pecuária e Abastecimento. Glossário ilustrado de morfologia. Ministério da Agricultura, Pecuária e Abastecimento. Secretaria de Defesa Agropecuária. Brasília: MAPA/ACS, 2009a. 406p. http://www.agricultura. gov.br/assuntos/insumos-agropecuarios/arquivos-publicacoesinsumos/10829_glossario_ilustrado_morfologia-3.pdf

BRASIL. Ministério da Agricultura, Pecuária e Abastecimento. Regras para análise de sementes. Ministério da Agricultura, Pecuária e Abastecimento. Secretaria de Defesa Agropecuária. Brasília: MAPA/ACS, 2009b. 395p. http://www.agricultura.gov.br/assuntos/ insumos-agropecuarios/arquivos-publicacoes-insumos/2946_ regras_analise_sementes.pdf

BRASIL. Ministério da Agricultura, Pecuária e Abastecimento. Instruções para análise de sementes de espécies florestais. Ministério da Agricultura, Pecuária e Abastecimento. Secretaria de Defesa Agropecuária. Brasília, DF: MAPA/SDA, 2013. 97p. http://www. agricultura.gov.br/assuntos/laboratorios/arquivos-publicacoeslaboratorio/florestal_documento_pdf-ilovepdf-compressed.pdf

CARDOSO, B.M.; DE MELLO, T.F.; LERA, D.S.; BRENZAN, M.A.; CORTEZ, D.A.; DONATTI, L.; SILVEIRA, T.G.; LONARDONI, M.V. Antileishmanial activity of a Calophyllum brasiliense leaf extract. Planta Medica, v.83, p.57-62, 2017. https:// www.thieme-connect.de/DOI/DOI?10.1055/s-0042-107673

DOMENEGHETTI, L.; DEMARCHI, L.G.; CAITANO, J.Z.; PEDROSO, R.B.; SILVEIRA, T.G.V.; LONARDONI, M.V.C. Calophyllum brasiliense modulates the immune response and promotes Leishmania amazonensis intracellular death. Mediators of Inflammation, v.2018, p.1-9, 2018. https://www.hindawi.com/ journals/mi/2018/6148351/abs/

FERREIRA, R.A.; BARRETTO, S.S.B. Caracterização morfológica de frutos, sementes, plântulas e mudas de pau-brasil (Caesalpinia echinata Lamarck). Revista Árvore, v.39, n.3, p.505-512, 2015. http:// www.scielo.br/pdf/rarv/v39n3/0100-6762-rarv-39-03-0505.pdf

GARCIA, W.R.; ESTRADA-MUNIZ, E.; VALVERDE, M.; VEGA, L. Cytogenetic effects of Jacareubin from Calophyllum brasiliense on human peripheral blood mononucleated cells in vitro and on mouse polychromatic erythrocytes in vivo. Toxicology and Applied Pharmacology, v.335, p.6-15, 2017. https://www-sciencedirect.ez22. periodicos.capes.gov.br/science/article/pii/S0041008X17303903
GÓMEZ-VERJAN, J.C.; RIVERO-SEGURA, N.A.; ESTRELLAPARRA, E.; RINCÓN-HEREDIA, R.; MADARIAGA-MAZÓN, A.; FLORES-SOTO, E.; GONZÁLEZ-MELJEM, M.; ERBÓN, M.; REYES-CHILPA, R. Network pharmacology uncovers anticancer activity of Mammea-type coumarins from Calophyllum brasiliense. Planta Medica, v.85, n.1, p.14-23, 2019. https://www-thiemeconnect-com.ez22.periodicos.capes.gov.br/products/ejournals/ $\mathrm{html} / 10.1055 / \mathrm{a}-0660-0236$

GONÇALVES, E.G.; LORENZI, H. Morfologia vegetal: organografia e dicionário ilustrado de morfologia das plantas vasculares. São Paulo: Instituto Plantarum de Estudos da Flora, 2007. 448p.

GORDIN, C.R.B.; MARQUES, R.F.; MASETTO, T.E.; SCALON, S.P.Q. Germinação, biometria de sementes e morfologia de plântulas de Guizotia abyssinica Cass. Revista Brasileira de Sementes, v.34, n.4, p. 619-627, 2012. http://www.scielo.br/pdf/rbs/v34n4/13.pdf

ISAIAS, D.E.B.; NIERO, R.; NOLDIN, V.F.; CAMPOS-BUZZI, F.; YUNES, R.A.; DELLE-MONACHE, F.; CECHINEL-FILHO, V. Pharmacological and phytochemical investigations of different parts of Calophyllum brasiliense (Clusiaceae). Pharmazie, v.59, n.11, p. 879-881, 2004. https://www.ingentaconnect.com/content/govi/ pharmaz/2004/00000059/00000011/art00015?crawler=true

LEMOS, L.M.S.; MARTINS, T.B.; TANAJURA, G.H.; GAZONI, V.F.; BONALDO, J.; STRADA, C.L.; SILVA, M.G.; DALL'OGLIO, E.L.; SOUSA-JÚNIOR, P.T.; MARTINS, D.T.O. Evaluation of antiulcer activity of chromanone fraction from Calophyllum brasiliesnse camb. Journal of Ethnopharmacology, v.141, n.1, p.432-439, 2012. https://www-sciencedirect.ez22.periodicos.capes. gov.br/science/article/pii/s0378874112001547?via\%3dihub

LEMOS, L.M.S.; MIYAJIMA, F.; CASTILHO, G.R.C.; MARTINS, D.T.O.; PRITCHARD, D.M.; BURKITT, M.D. Hexane extracts of Calophyllum brasiliense inhibit the development of gastric preneoplasia in Helicobacter felis infected INS-gas mice. Frontiers in Pharmacology, v.8, n.92, p.1-11, 2017. https://www.frontiersin. org/articles/10.3389/fphar.2017.00092/full

OLIVEIRA, V.C.; JOLY, C.A. Flooding tolerance of Calophyllum brasiliense Camb. (Clusiaceas): morphological, physiological and growth response. Trees, v.24, n.1, p.185-193, 2010. https://link. springer.com/article/10.1007/s00468-009-0392-2

REA, A.; TEMPONE, A.G.; PINTO, E.G.; MESQUITA, J.T.; RODRIGUES, E.; GRUS, M.; SILVA, L.; SARTORELLI, P.; LAGO, J.H.G. Soulamarin isolated from Calophyllum brasiliense (Clusiaceae) induces plasma membrane permeabilization of Trypanosoma cruzi and mytochondrial dysfunction. PLOS Neglected Tropical Diseases, 2013. https://journals.plos.org/plosntds/ article?id=10.1371/journal.pntd.0002556

RAMOS, M.B.P.; FERRAZ, I.D.K. Estudos morfológicos de frutos, sementes e plântulas de Enterolobium schomburgkii Benth. (Leguminosae-Mimosoideae). Revista Brasileira de Botânica, v.31, n.2, p.227-235, 2008. http://www.scielo.br/pdf/rbb/v31n2/ v31n2a05.pdf

SCHULTZ, J. Calophyllum brasiliense: Olandi. In: CORADIN, L.; SIMINSKI, A.; REIS, A. Espécies nativas da flora brasileira de valor econômico atual ou potencial: plantas para o futuro - Região Sul. Brasília: MMA, 2011. p.440-443. 
SEUBERT, R.C.; MAÇANEIRO, J.P.; BUDAG, J.J.; FENELLI, T.A.B.; SCHORN, L.A. Banco de sementes do solo sob plantios de Eucalyptus grandis no município de Brusque, Santa Catarina. Revista Floresta, v.46, n.2, p.165-172, 2016. https://revistas.ufpr.br/ floresta/article/download/38191/28530

SILVA, K.B.; ALVES, E.U.; BRUNO, R.L.A.; MATOS, V.P.; GONÇALVES, E.P. Morfologia de frutos, sementes, plântulas e plantas de Erythrina velutina willd., leguminoseae - Papilionideae. Revista Brasileira de Sementes, v.30, n.3, p.104-114, 2008. http:// www.scielo.br/pdf/rbs/v30n3/14.pdf

SILVA, R.C.; VIEIRA, E.S.N.; PANOBIANCO, M. Técnicas para superação de dormência de sementes de guanandi. Pesquisa Agropecuária Brasileira, v.49, n.9, p.719-727, 2014. http://www.scielo.br/scielo. php?script=sci_arttext\&pid=S0100-204X2014000900719

SILVA, R.C.; VIEIRA, E.S.N.; PANOBIANCO, M. Morphophysiological characteristics of guanandi fruit and seeds during ripening and harvesting time. Pesquisa Agropecuária Brasileira, v.53, n.2, p.212-220, 2018. http://www.scielo.br/pdf/pab/ v53n2/1678-3921-pab-53-02-212.pdf
SOUZA, L.A. Morfologia e anatomia vegetal: célula, tecidos, órgãos e plântula. $1^{\mathrm{a}}$ ed. Ponta Grossa: Editora UEPG, 2009. 259p.

TEIXEIRA, C.C.; BARBEDO, C.J. The development of seedlings from fragments of monoembryonic seeds as an important survival strategy for Eugenia (Myrtaceae) tree species. Trees, v.26, n.3, p.1069-1077, 2012. https://link.springer.com/ article/10.1007\%2Fs00468-011-0648-5

VIDAL, W.N.; VIDAL, M.R.R. Botânica organografia: quadros sinóticos ilustrados de fanerógamos. $4^{\mathrm{a}}$ ed. Viçosa: UFV, 2007. 124p.

VOGEL, E.F. Seedling of dicotyledons: structure, development, types: descriptions of 150 woody Malesian taxa. Centre for Agricultural Publishing and Documentation. Wageningen: Netherlands, 1980. 465p. 